\title{
EXPLORATION OF URBAN INTERACTIVE KIOSKS CENTERED ON INTERFACE ERGONOMY AND USER EXPERIENCE
}

\author{
Mehmet Sinan YUM1* \\ 1 İstanbul Commerce Üniversity, Faculty of Architecture and Design, Department of Industrial Design \\ ORCID No: http://orcid.org/0000-0002-0869-2967
}

\begin{tabular}{ll}
\hline Keywords & Abstract \\
\hline Digital Kiosks & The study encompasses the exploration of urban interactive kiosks according to the \\
Ergonomics & determined criteria based on physical properties, interface features and service types. \\
Interaction & The main purpose of this approach is to create an infrastructure for the evaluation of \\
Interface Design & the aquarium kiosk presented as a case study project by examining products with \\
User Experience & different functions, locations and product characteristics. As a result of technological \\
progress, interactive kiosks maintain various services with consistency for public use. & In contemporary life, kiosks provide services that speed up daily operations with their \\
informative, explanatory and regulative content. The study based on a qualitative & approach covers the evaluation of the interaction types, service goals and content \\
related information of kiosks used for public services in terms of interface ergonomics \\
and aesthetical features forming user experience. Following the explanation of \\
essential literature input that constitutes the study, concepts related to interface \\
ergonomics and virtual ergonomic features of kiosk are elaborated with the inclusion \\
of the project discussed. In the discussion section aligned with the goals of the study, \\
the service kiosk designed with participation of the author for the Istanbul Aquarium \\
is presented, explained and evaluated in order to create a connection and comparison \\
among the examples provided. By achieving an essential foundation for the \\
comparison, the study aims to determine the similarities and differences between the \\
kiosks built for public and private use through the application of a common set of \\
evaluative criteria.
\end{tabular}

\section{ŞEHIRLERDEKI ETKILEŞIMLI KIOSKLARIN ARAYÜZ ERGONOMISI İLE KULLANICI DENEYIMI EKSENINDE INCELENMELERI}

\author{
Anahtar Kelimeler \\ Arayüz Tasarımı \\ Dijital Kiosk \\ Ergonomi \\ Etkileşim \\ Kullanıcı Deneyimi
}

\section{Öz}

Çalışma, kentsel etkileşimli kioskların fiziksel özellikleri, arayüz özellikleri ve hizmet türlerine göre belirlenen kriterlere göre incelenmesini kapsamaktadır. Bu yaklaşımın temel amacı, farklı işleve, konuma ve ürün özelliklerine sahip kioskların incelenmesiyle vaka çalışması projesi olarak sunulan akvaryum kioskunun değerlendirilmesi için altyapı oluşturulmasıdır. Teknolojik ilerlemenin bir sonucu olarak etkileşimli kiosklar, çeşitli hizmetleri kamu kullanımı için düzenli bir şekilde sürdürmektedir. Çağdaş yașamda kiosklar bilgilendirici, açılklayıcı ve düzenleyici içerikleriyle günlük operasyonları hızlandıran hizmetler sunmaktadır. Nitel bir araştırma olan çalışma, kamusal hizmetlerde kullanılan kioskların etkileşim türleri, hizmet hedefleri ve içerikle ilgili özelliklerinin kullanıcı deneyimi sağlayan arayüz ergonomisi ve fiziksel ergonomi açısından değerlendirilmesini kapsamaktadır. Çalışmayı oluşturan temel literatürün açıklanmasının ardından, tartışma bölümü projesinin dahil edilmesiyle hizmet kiosklarının arayüz ve sanal ergonomi özellikleri incelenmektedir. Bu bağlamda tartışma bölümünde, Istanbul Akvaryumu için yazarın katılımıyla tasarlanan etkileşimli kiosk ile sunulan kamusal hizmet kioskları incelenerek ürünler arasında karşılaștırma yapılması ve ilișki kurulması hedeflenmektedir. Çalışma, ürünlerin karşılaştırılması amacıyla ortak değerlendirme ölçütlerine dayanan bir altyapı sunmaktadır. Araştırmada kamu ve özel kullanım için üretilen kiosklar arasındaki benzerlik ve farklılıkların belirlenmesiyle ürünlerin hizmet, içerik, ergonomi ve arayüz özellikleri konularında kazanımlar sağlanmasını hedeflemektedir. Bu amaçla kent mobilyası olarak algılanan kioskların şehir estetiğine katkısı, hizmet becerileri, içerik ve etkileşim tipleri ile ergonomik özellikleri incelenmektedir.

\begin{tabular}{llll}
\hline Araştırma Makalesi & \multicolumn{3}{c}{ Research Article } \\
Başvuru Tarihi & $: 31.01 .2021$ & Submission Date & $: 31.01 .2021$ \\
Kabul Tarihi & $: 05.03 .2021$ & Accepted Date & $: 05.03 .2021$ \\
\hline
\end{tabular}

\footnotetext{
${ }^{*}$ Corresponding author e-mail: msyum@ticaret.edu.tr
} 


\section{Introduction}

The subject of the research is the exploration of public service kiosks in order to provide an evaluative infrastructure for the case study kiosk. The importance and relevance of the subject is based on the explorative goals on a product designed by the author. Design process regarding the product is centered on content creation and user experience implying to the original qualities of the product developed in a custom project. The research also explores multiple public kiosks on various qualities that render these products adapt for service. The original value and academic contribution of the study is the scope of creating a connection between a custom product developed for user experience goals compared to public kiosks developed for service performance. The main problematic regarding the field of research is the lack of design qualities of public service kiosks based on interface and physical ergonomic as well as aesthetical features. Primary indicators of the problem encompass the physical qualities, primitive interfaces and service qualities of public kiosks. In regard to the problems mentioned, the study analyzes public kiosks based on the evaluation charts presented focusing on the abovementioned qualities of products. During the research stage for the study, it has been observed that many public kiosks do not function properly, some are physically repulsive and users tend to spend too much time trying to figure out the functionality aspects of products. This observation has the capacity to lead to the conclusion that most public kiosks lack significant characteristics regarding user experience.

Primarily public kiosks mostly lack the relation between physical and virtual qualities centered on interaction design. In order to find a solution to the problem, the study proposes a product developed on user experience goals that has the potential to layout a foundation on which public service kiosk can be reconsidered during conceptual design stages. Therefore, it may be possible to theorize that coming up with a design approach that encompasses physical and virtual design of products in an integrated manner based on user experience methods may aid in enhancing the overall quality of products. In this context, the case study kiosk has a potential of proposing a user experience design model for public service kiosks as evaluating a product that has been in service for the last 7 years without serious maintenance problems may provide an insight on the matter.

The main hypothesis of the article is 'Interactive kiosks designed for user experience provide an enhanced service and experience outcomes'. Designing a product based on user experience has multiple benefits as qualities on service are not sufficient in a time of interaction and smart devices. Most public kiosks do not provide real-time feedback regarding service performance and technical issues. The case study kiosk placed in the aquarium is being monitored 24/7. So, if the system crashes, the software places a warning mechanism for the administrators prompting for maintenance. This idea could also provide a solution regarding the service quality of public kiosk from a designer point of view. Designing a product based on user experience enhances the quality of service enabling the monitoring of feedback, technical issues, usage frequency and related matters.

Interactive kiosks are used in various public structures such as ferry ports, bus stops, concert and universities, located at central points in cities for easy access. Kiosks that provide services to all types of user identities are designed with the aim of presenting service diversity and informative content in the most effective way. These products also increase architectural perception in order to contribute to spatial experience. In some cases, the users are not able to obtain the essential efficiency from the system. This situation results as not being able to reach service goals due to failure in terms of interface ergonomics features of the system creating boredom. In such cases, general lack of functionality is explained as the instability of the system. Quick and trouble-free service for users is important for the quality of service provided by such interactive units. In times of technological implementations, people are in a process where they try to understand the meaning of products for themselves, rather than perceiving them through their physical properties (Narter, 2019). As mentioned by (Stone \& Wood, 2000), functional models represent a form independent blueprint of the product as a consistent language is required to ensure the readability of the object. Therefore, it is expected that the experiences provided offer a meaningful outcome in terms of product-user relationship, product language (Stone \& Wood, 2000) and readability (Narter, 2019). In accordance with the developing design forms, it is important that designers consider their tasks and goals in detail, evaluating product development processes oriented on user experience. For this purpose, concepts related to the title and keywords are explained in line with the objectives of the study.

\section{Literature Review}

Sosyal medya üzerinde sosyal ağ analizleri, farklı The section presents terms related to the topic based on the literature review presented. The methodological structure of the study is based on the support of the sections presented in an integrated manner. For this purpose, the functional structure of the study consists of an introduction, development, causality, 
research and a results section. The structure described in the visual presented explains the process and stages of the research.

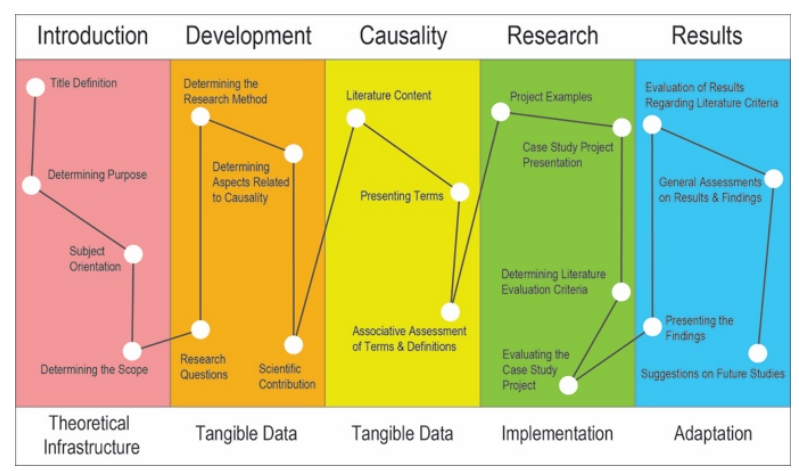

Figure 1. Methodological Structure

The introduction part covers the theoretical background of the research. Within the section, the positioning of the study is explained by determining the title, purpose, orientation and scope. In this context, the study examines and evaluates the features centered on ergonomics of interactive kiosks used in cities that offer different services in urban life. In order to provide and orientation regarding the study, the research includes the evaluation of the case study product designed by the author based on the findings obtained as a result of the presentation and evaluation process' of examples.

The development section is the first section in which theoretical data is presented aimed to determine the research questions, method, causality, original value and scientific contribution in the study. In this context, 'What are the ergonomic and service features of public space kiosks; What are the features of kiosks in centered on design and ergonomics; What are the multidisciplinary features of kiosks? are the questions of which the study aims to respond. The study is a qualitative research based on the identification of service kiosks and the examination and documentation of their service-based functions. The causality value of the research is centered on the detection and evaluation of the differences of a product designed by the author compared to public service kiosks. The original value of the study contributing to the research, is the focus on a product that is a part of a professional project and the academic approach in which both are handled in an integrated manner, aiming to achieve gains on both aspects of the profession.

The causality section of the study consists of tangible data aimed at presenting the basic concepts related to the title and keywords that make up the research. For this purpose, within the framework of the literature created for the study, important concepts are presented and associated as well as new concepts being explained in relation to one another.

The research section includes the implementation examples described in the study. The visual and functional data collected on public service kiosk examples are presented and explained, creating an infrastructure for the product presentation made by the author. By relating and explaining the literature evaluation criteria with the concepts presented in the section, all products are evaluated according to the compiled criteria.

The conclusion section of the study covers the positioning of the adaptation results in line with the objectives of the study. In the section, findings related to the evaluation process are presented, results are evaluated, general results of the study are explained, and recommendations are made for future studies.

\subsection{Ergonomics}

The concept of 'ergonomics', which refers to science of labor, originates from the Greek word ergo. The term was used for the first time in 1949 by scientists working on problems related to the harmony between man and daily chores (Laville, 1976). In modern times, measures need to be taken in order to guarantee the safety of employees who are in constant interaction within the working area. It is essential to eliminate the factors that adversely affect the health of individuals working in any line of business. The necessity of organizing this need based on scientific criteria, has led to the concept of ergonomics. The task of organizing the required change falls to ergonomics and it has become obligatory that design and arrangement of workplace organization are managed according by these rules for the preservation of employee health. Since ergonomics is a cross-sectional science in general, it is possible to explain the factors that are examined, associated and evaluated as shown below.

a) Anatomical factors refer to the measurement of individuals' body shape and proportions in terms of race, age and gender.

b) Psychological factors express the support of positive influencing elements such as color, order, decoration and music in work environment.

c) Physiological factors refer to minimizing individual stress levels and ensuring that the working environment is brought to the highest level of efficiency.

The concept of ergonomics has shifted from tangible to abstract as a result of the addition of features related to interface ergonomics on virtual and digital 
designs. In the last 20 years, spatial or physical designs and products are developed according to ergonomic constraints in order to provide a higher user experience. In terms of tangible products, it is necessary to provide the operational comfort by adapting to variable situations during the service period. Product design methods create intersections with semantic approaches and combine the symbolic functions of products with design-related areas such as physical, ergonomic and aesthetic functions (Bayrakçı, 2004). This situation reveals the multidisciplinary nature of designing products. Designed according to principles on ergonomics, the product, space or furniture needs to be developed in a way that allows usages depending on individual differences, offer functional competence and a healthy working space.

With the increase in time at work and decreasing quality jobs, some physical and psychological disorders occur in employees. Physical problems are generally caused by the inappropriateness of working conditions regarding physicality and anthropometry. The causes of psychological problems differ, factors such as disturbing colors, loud noise and stuffiness can negatively affect the psychology of the employees. For this reason, it is necessary to consider all relevant factors together in order to ensure satisfying working conditions. It is only appropriate to evaluate and define the concept of ergonomics by considering all its domains together. In this context, ergonomics can be considered as a science focusing on individual and collective psychology, anthropometry, physiology that determines, develops and implements the qualities of all factors necessary for individuals to work efficiently, healthily and comfortably in a work environment.

\subsection{Human-Computer Interaction and Information Ergonomics}

In this research, as in line with the objectives of the study, the concept of ergonomics is examined in terms of the usages on interactive kiosks used in public spaces. Kiosks presented are evaluated in terms of physical, virtual interface ergonomics and achievements on service. Human-computer interaction (HCI) is a term scientifically used to describe the interaction that takes place through both on physical and virtual interfaces with the users. Concept of HCI expresses how and in what ways users interact with kiosk, computers with mostly touchscreen hardware. It is possible to list the design-related qualities of virtual interfaces, which are basically communicative agents between the user and machine (Reed et al., 1999). These features can be expressed as a design-oriented familiar look and feel, consistency ensuring, usage feedback data preservation, usability evaluation and adaptation to changing requirements. The positive effect of design and accomplished service features on users can be defined as user experience.

In an attempt to examine daily smart devices, it is possible to claim that interaction is often a virtual process triggered by touch controls and rarely through a physical interface consisting of buttons. The change began in the 80's and computer science, with the emergence of the HCI concept based on cognition. By determining and developing the form and other characteristics of communication between human and computer, the experience provided by user-friendly devices has gained a marketable quality. Fogg (2002), states that technology provides positive feedback by motivating users to change behavior and by guiding them. This statement shows that especially smart devices with artificial intelligence have the ability to manage and manipulate themselves according to their user identities. In order to present a device that serves many, user identities need to be examined in order to design ergonomic user interfaces focused on customizability.

Service-oriented communicative products need to be designed in accordance with societies of different demographic characteristics, also be suitable for individuals with disabilities. Integrated principles on design and sociology enables the production of functional devices for members of society with different inability that ensure the service quality of HCI devices. Accessibility is a term used for describing the delicate development procedure of products for disabled citizens. Products designed in accordance with accessibility rules are products that have the ability to serve all individuals in a society by complying with universal design criteria. With the scope of developing products and contents that have the potential to provide service for everyone including individuals with inabilities, it is essential to maintain a design model based on information ergonomic principles that encompasses a wide range of regulatory guidelines. Information ergonomics is a field related to HCI and consists of variables that can be explained as user type, task properties, system configuration and environment. User type refers to user typology, meanwhile task properties is related to a positive functionality. System configuration refers to the information architecture of any content allowing users to navigate without getting lost and environment is the location in which the device has been placed. User types represent the provision of services within the framework of accessibility rules suitable for each user identity. Task properties define the provision of visual cues to users who make mistakes or show low interest. Interface design characteristics are easy to identify by the visual separation of the elements that make up 
the interface, allowing the operations to be carried out quickly.

\subsection{Interface and Design}

Interfaces are communication mediums of graphic design creating the interaction between computer and user. Almost every smart object, electronic devices and interactive products has an interface by means to assign control to the user. In order to design a utilitarian product, the functionality depends on the informative qualities of the interface as well as the mechanism of the object. Interfaces are usage screens required to control the virtual functions of many devices and should be designed in accordance with the device's form, user identities and service targets.

Ergonomics is the most important factor affecting the quality of user experience on interactive systems. A well-designed software interface that fulfills its purpose presents important advantages such as increasing the quality of the work done, increasing the satisfaction level of the user, increasing the productivity of the workforce and ensuring the security of the system controlled by the software (Liu, 1997). Ease of use of any interface is related to familiarity to the system, prior experience and personal preferences of the user. Engagement is a term used in user experience referring to the balance between the task difficulty and cognitive skills of a person (Csikszentmihalyi, 1998). In time immersion occurs and engagement span increases. Positive individual performance is related to terms such as engagement, motivation and immersion values related to user experience.

Interfaces translate machine language to user language and vice versa. This process results in controlling the device and reaching the informative content. Basic tangible interfaces have evolved into digital graphic interfaces allowing them to occupy less space and offer more content on objects. This quality shows the success of an integrated design approach, uniting product, graphic and digital design. Most important property of digital interfaces compared to analog interfaces is the capacity to provide information on the system as feedbacks. Feedback occurs when interfaces transmit information received from the system to users and provide status reports when the system is working properly or there is a problem. Interfaces can be classified as visual and auditory, visual interfaces create a channel that communicates between the system and the user by sense of sight, through symbols, pictograms, colors and text. Auditory interfaces communicate by sense of hearing. Guidance is provided by cognitively processing information on sound such as intensity, frequency, and direction.
User-product interface is the sum of design decisions that enable users to use the product. While designing the interface, the aim is to achieve high efficiency by providing enhanced user-product communication (Yum, 2015). As a result of developments in information technologies and widespread use of computers, studies on interface design have largely focused on user-software interface design. While interface design previously covered the mental, psychological and physical properties of interfaces, recently the focus shifted to the cognitive aspects related to information technologies. Information architecture design has become a major field for the assessment on different methods of software-based navigation. In the past, users were in direct interaction with the product or system through the use of analog controls. In the last 20 years or so with the intervention of digital software interfaces, interaction became indirect and virtual. Today in most devices users no longer control the system directly, but a representational interface that creates a sub-proxy mechanism on behalf of the user. Apart from the aforementioned interfaces, studies are carried out on kinesthetic, tactile and gustatory interfaces. As a result of the research that has been done, it is possible to claim that the design success of the interfaces highly affects the communicative and service-oriented efficiency of systems.

\subsection{Interactive Kiosks}

Kiosk is a system that consist of a microprocessor controlled computer and a touch screen. Computers are stored in specially designed cases outdoors or contained areas indoors for ease of use in order to prevent damage from the elements and public harassment. The usage areas of kiosks are increasing daily with many offered opportunities on communication for companies especially in the fields of sales and marketing. Interactive kiosks are also used as systems that respond to users' requests such as buying tickets for any activity, making reservations or even placing orders. Kiosks are preferred for various services to be positioned in public buildings such as shopping malls, supermarkets, theaters and hotels due to their easy transportation, low installation cost and practical dimensions. In addition to being used in any structure, the fact that interactive kiosks are suitable for remote access, collect user information and provide services that do not require manpower, are the main reasons for their prefer ability in public spaces. Kiosks used in public areas have different functions. While functions sometimes determine the form, the design prediction of the designer often determines the form. The aim of kiosks used for service-oriented requirements is to provide the service more efficiently and quickly (Swamy et al., 2016). 


\section{Method}

Interactive kiosks used in cities provide services at high frequencies. In the study, these products are evaluated according to the determined criteria. The laboratory project product is a kiosk used at special frequencies included in an edutainment scenario (Brandejsky \& Kilzer, 2006). It is evaluated according to the presented criteria just as previously provided examples. The study is based on the results of 2 different evaluation processes and revealing the common features and distinctive features of kiosks designed for general and specific use centered on user experience.

Organizing daily objects in a way to ease the experience is one of the most important duties of design and the main challenge in such a task, falls under the responsibility of ergonomics. Kavut (2019), evaluated the relationship between ergonomics and technology through the development of kitchens in homes and in his research, emphasizes the importance of organizing storage, cleaning and cooking functions according to the material characteristics, social factors and physical needs of the users. Even though the scale could differ, the relationship between technology and ergonomics exists in kiosks providing public service in contemporary life. Kiosks are in constant interaction with the space, increase the spatial perception and create a user experience by updating traditional approaches and values through the replacement of many services provided by people.

In the discussions section, initially kiosks used in public spaces in Istanbul are presented followed by a kiosk designed for the Istanbul Aquarium 'edutainment' project with the participation of the author. These products are presented and evaluated according to the selected criteria from the presented literature, recorded observations and specifications on subject product. Kiosks that are designed and implemented as Edutainment Design products establish physical and cognitive communication with the visitors. There are various studies belonging to the author based on edutainment design evaluating various projects. The section presents and evaluates the public kiosks in relation to the criteria list and repeats the process for the case study kiosk. Two different approaches on kiosks are preferred in line with the objectives of the study. The kiosks explained as examples are selected from urban regions where users are likely to reach the highest usage frequencies, meanwhile the kiosk presented as case study is a product designed and produced with the contribution of the author. A score system has been implemented on the evaluation data in order to validate the quality of products. The evaluation criteria selected in order to examine the products presented can be listed as shown below. a) Dimensions: Information about the dimensions of the kiosk (Stone \& Wood.2000; Narter,2019)

b) Service Quality: Intensity of use. (Jengchung et al, 2015; Berkley \& Gupta, 1994)

c) Technological Aspects: Digital content touch technologies. (Lao et al.2009)

d) Ergonomics: Ergonomic related value according to equivalent products.

e) Interface Quality: User experience value. (Blair-Early \& Zender,2008).

f) Operational Details: Providing information on product specific working style.

g) Design Orientation Features: Industrial design, digital interaction design (Ekşioğlu, 2016)

h) Spatial orientation: Location information.

i) Infrastructural features: Providing information on energy infrastructure.

j) Interaction Types: Quality of interaction (Shedroff, 1994)

k) Screen interaction styles: Single-touch (Hagen \& Sandnes ,2010).

The criteria included in the list are intended to provide information on ergonomics, user experience, infrastructure, technology used and other relevant qualities in order to offer an enhanced service. Presented products are evaluated according to the listed criteria, and a joint evaluation is provided between the products used in public services and the kiosk designed by the author for the aquarium project.

\subsection{Evaluation of Public Service Kiosks}

The kiosks selected for the study are products that work in public areas in order to provide various services. Some of these services are of traditional nature like ticket sales, meanwhile some of them for example bike rental, are services brought by the possibilities of interaction. Kiosks used for municipal service purposes are located on the junction points of the city such as ferry piers, subway stops and schools. In this context, the performance, ergonomics and aesthetic qualities of 10 interactive kiosks presented are evaluated according to the determined criteria. The purpose of the evaluation regarding the current usage products is to create the infrastructure necessary for the positioning and reference of use, in order to evaluate the laboratory product in accordance with the criteria. Figure 1 presents the urban service kiosks selected by the author for the evaluation process. 


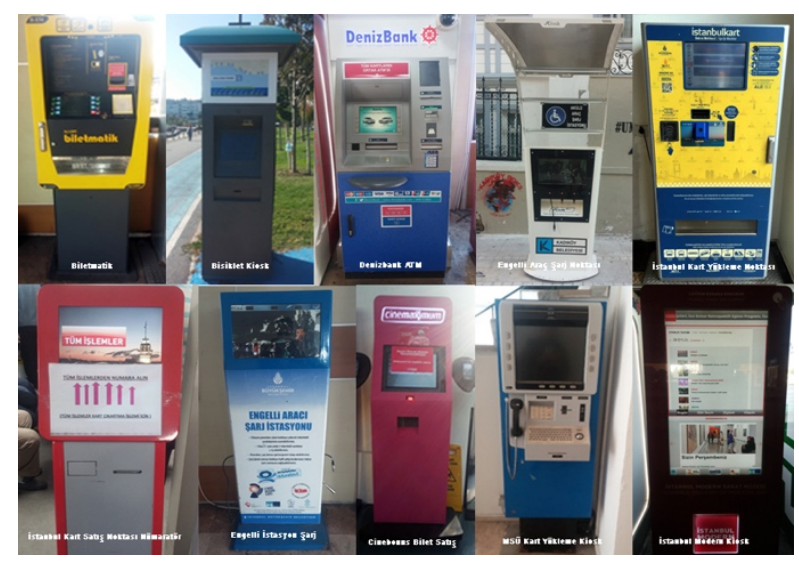

Figure 2. Public Service Kiosks (Yum, 2019)

In order to evaluate the kiosk of different design and content, as presented in the visual in terms of ergonomics, interface and user experience, evaluations are presented in the section. The evaluation criteria consist of two groups of content. The first group is based on literature-centered research findings and the second group is based on observation, product usage frequencies and user feedback. For this purpose, the criteria are explained below. Dimensions of kiosks provide a general sense on physical aspects of kiosks and screens. Physically kiosk presented can be considered as adequate products even though size, form and dimension may vary. Jengchung et al. (2015) mentions that interactive kiosks are commonly used in the service industry in order to provide results on efficiency, the chart presents an analysis of product service qualities based on the criteria compiled from the research by (Berkley \& Gupta, 1994). User interface features of kiosk generally depend on touch technologies and analog systems as referred to by (Lao et al., 2009; Hagen \& Sandnes, 2010). Other relevant technologies such as gesture recognition (Chaudhary et al., 2010) do not apply for these kind of products, as of yet. Ergonomic qualities of products are evaluated based on the input provided by physical and virtual compatibility as a crossover of overall dimensions and digital interface centered quality assessments. Blair-Early \& Zender (2008), defines user interface design as the means by which users interact with content to accomplish some goal. Hagen \& Sandnes (2010), has conducted studies on intelligent user interfaces in kiosk with the scope of user experience focusing $\mathrm{n}$ screen interaction types. Operational details refer to the functionality and service-centered aspects of kiosks. Design orientation refers to design related qualities of products providing evaluation in order to determine the multidisciplinary nature of kiosks (Ekşioğlu, 2016). Location presents the position of the product urbanistically and structurally. Infrastructural information refers to the energy requirements of products. Shedroff (1994), classifies interaction types as direct, indirect and accidental depending on the procedural reciprocity between the user and system. Interaction type of digital kiosks are based on direct interaction through physical manipulation as interaction takes place on cognitive level matching with psycho-motor skills belonging to the user by choice. The score system is based on the evaluation of selected qualities on decimal bases, implying to the fact that (10) points is the maximum cap for each quality. Evaluations compiled for each kiosk is important in determining the qualities of products in order to reach the essential findings in line with the objectives of the study.

a) Belbim Biletmatik Evaluation: Dimensions: $158 \mathrm{~cm}$ x $60 \mathrm{~cm}$ Screen H: $112 \mathrm{~cm}$, Service Quality: 9, Technological Aspects: Touchscreen, Ergonomics: 8, Interface Quality: 7, Operational Details: Cash Slot, Design Orientation Features: Industrial, Digital Interaction, Spatial Orientation: Harbour, Infrastructural Features: Municipal, Interaction Types: Direct, Screen Interaction Styles: SingleTouch.

b) Bicycle Rental: Dimensions: $200 \mathrm{~cm}\urcorner+, 65 \mathrm{~cm}$, Service Quality: 5, Technological Aspects: Touchscreen, Ergonomics: 7, Interface Quality: 4, Operational Details: Pos Unit, Design Orientation Features: Industrial, Digital Interaction, Spatial Orientation: Coastal Driveway, Infrastructural Features: Municipal, Interaction Types: Direct, Screen Interaction Styles: Single-Touch.

c) Denizbank ATM: Dimensions: $200 \mathrm{~cm}+, 84 \mathrm{~cm}$, Service Quality: 10, Technological Aspects: Touchscreen, Ergonomics: 5, Interface Quality: 5, Operational Details: Cash Slot, Design Orientation Features: Industrial, Digital Interaction, Spatial Orientation: Urban Locations, Infrastructural Features: Municipal-UPS, Interaction Types: Direct, Screen Interaction Styles: Single-Touch.

d) Vehicle Charge Point: Dimensions: $200 \mathrm{~cm}+$, $64 \mathrm{~cm}$, Service Quality: 5, Technological Aspects: Touchscreen, Ergonomics: 7, Interface Quality: 6, Operational Details: Charge Slot, Design Orientation Features: Industrial, Digital Interaction, Spatial Orientation: Süreyya Opera House, Infrastructural Features: Municipal, Interaction Types: Direct, Screen Interaction Styles: Single-Touch.

e)Istanbul Card: Dimensions: $170 \mathrm{~cm} \times 73 \mathrm{~m}$ Screen H: 140,30x33cm, Service Quality: 10, Technological Aspects: Touchscreen, Ergonomics: 8, Interface

Quality: 9, Operational Details: Cash Slot, Design Orientation Features: Industrial, Digital Interaction, Spatial Orientation: Harbour, Infrastructural Features: Municipal, Interaction Types: Direct, Screen Interaction Styles: Single-Touch. 
f) Numerator: Dimensions: $120 \mathrm{~cm} \times 43 \mathrm{~cm}$, Service Quality: 10, Technological Aspects: Touchscreen, Ergonomics: 10, Interface Quality: 9, Operational Details: Cash Slot, Design Orientation Features: Industrial, Digital Interaction, Spatial Orientation: Istanbul Card Center, Infrastructural Features: Municipal, Interaction Types: Direct, Screen Interaction Styles: Single-Touch.

g)Istanbul Modern Digital Board: Dimensions: $200 \mathrm{~cm} x 84 \mathrm{~cm}$, Screen H: $83.5 \mathrm{~cm}$, Service Quality: 10, Technological Aspects: Screen, Ergonomics: 4, Interface Quality: Visual Content, Operational Details: Cash Slot, Design Orientation Features: Industrial, Digital Interaction, Spatial Orientation: Harbour, Infrastructural Features: Municipal, Interaction Types: Visual \& Cognitive, Screen Interaction Styles: None.

h)MSU RFID Kiosk: Dimensions: $160 \mathrm{~cm} \times 52 \mathrm{~cm}$, Service Quality: 10, Technological Aspects: RFID, Touchscreen, Ergonomics: 7, Interface Quality: 9, Operational Details : Cash Slot, Design Orientation Features: Industrial, Digital Interaction, Spatial Orientation: Food Court, Infrastructural Features: Structural, Interaction Types: Direct, Screen Interaction Styles: Single-Touch.

i)Cinebonus Ticketmaster: Dimensions: $200 \mathrm{~cm} x 47 \mathrm{~cm}$, Service Quality: 10, Technological Aspects: Touchscreen, Ergonomics: 8, Interface Quality: 9, Operational Details: Cash/Ticket Slot, Design Orientation Features: Industrial, Digital Interaction, Spatial Orientation: Theaters, Infrastructural Features: Municipal, Interaction Types: Structural, Screen Interaction Styles: SingleTouch.

j)Disabled Vehicle Charge Station: Dimensions: $134 \mathrm{~cm} \times 51.5 \mathrm{~cm}$, Screen H: $106 \mathrm{~cm}$, Service Quality: 9, Technological Aspects: Touchscreen, Ergonomics: 8, Interface Quality: 8, Operational Details: Charge Cable Hardware, Design Orientation Features: Industrial, Digital Interaction, Spatial Orientation: Harbour, Infrastructural Features: Municipal, Interaction Types: Direct, Screen Interaction Styles: Single-Touch.

Results and findings of the evaluation process in regard to the case study product are explained in the next section of the study after the evaluation of the case study kiosk.

\subsection{Laboratory Project: Istanbul Aquarium}

Istanbul Aquarium is the world's largest thematic aquarium. There are 1500 species of marine and terrestrial creatures in the structure and experience is strengthened by high-tech interactive products. Overall edutainment scenario and content has been designed by a company partnered by the author.
Digital content designed has been placed in 39 INF 130 model 17" kiosks providing visual and physical interaction. The system provides an international database of fish found on the planet. Scientific content placed on kiosks is based on user experience with communicative styles befitting edutainment design implying to the game-like entertainment qualities of the implementations. Figure 2 shows the 'Fish Database' application kiosk designed for the Istanbul Aquarium project.

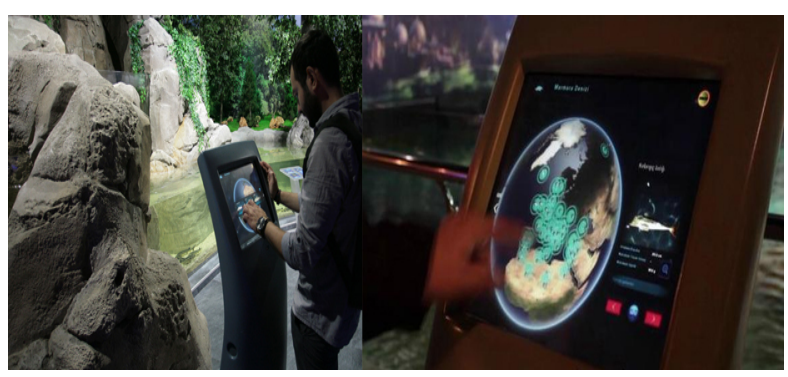

Figure 3. Fish Database (Yum, 2015)

As pre-made hardware found on kiosks does not support the $3 \mathrm{D}$ visualization requirements, the equipment has been updated and strengthened at the request of the designer firm. Kiosks that offer an interactive experience have been placed at the strategic points of the building in line with the edutainment scenario. Interactive kiosks provide information about the fish species living in seas and oceans. Products communicate by providing a playful user experience through touch technologies in terms of interface interaction and the system updates the newly added species to local fish database automatically.

\subsection{Laboratory Project: Evaluation of the Aquarium Kiosks}

In line with the objectives of the study, aquarium interactive fish database kiosks are evaluated upon the criteria used previously in order to make inferences on laboratory work. The study aims to create an objective assessment mechanism with the comparison of a personal project in relation to public service products. Interactive fish database kiosk assessment table is presented below. 
Table 1. Aquarium Kiosk Evaluation

Dimensions

$47 \mathrm{~cm} \times 42 \mathrm{~cm} \times 135 \mathrm{~cm}$

$\begin{array}{ll}\text { Service Quality } & 10 \\ \text { Technological Aspects } & \text { Touchscreen } \\ \text { Ergonomics } & 8 \\ \text { Interface Quality } & 10 \\ \begin{array}{l}\text { Operational Details } \\ \text { Base } \quad \text { Real time Data } \\ \quad \text { App }\end{array} \\ \begin{array}{l}\text { Design Orientation Features } \\ \quad \text { Interaction }\end{array} \\ \begin{array}{l}\text { Spatial Orientation } \\ \text { Infrastructural Features } \\ \text { Interaction Types }\end{array} \\ \begin{array}{l}\text { Screen Interaction Styles } \\ \text { Aquarium (39) }\end{array}\end{array}$

The results and findings of the evaluated interactive fish database kiosk are explained in the next section. It is important to keep in mind that content wise, the aquarium kiosk is a tailor-made gaming software with goals on edutainment that refers to the educative and entertainment qualities of the content.

\section{Kiosk Evaluation Results}

It is possible to layout the findings of the evaluation process on urban public and aquarium kiosks presented. The evaluations show the differences among kiosks and provide feedback on kiosk development process' setting the goals on design. Clearly, any kiosk should be designed based on the service goals and user identities, nevertheless all kiosks should respect ergonomic standards in order to enhance performance and experience. Regardless of the original content and interaction values of kiosks designed for the aquarium, it is possible to draw some conclusions on design qualities of all products are examined. In order to present a wide range of diverse products, kiosks selected for the study consist of various products used in various institutions, schools, municipal service and private sector. During the research stages, observation on site, video recordings and conversations with the users took place in order to collect data and receive feedback on the experience.

a) It has been observed that service success is related to the strength of interface designed, but the aesthetic success associated with industrial design, has no effect on kiosk performance. b) The dimensions show the compatibility of the products with anthropometric and ergonomic standards. Dimensions also have an effect on ensuring the noticeability of kiosks in their locations.

c) As informed by the Aquarium administrative team, digital feedback logs and data collected during the beta stages, kiosks used in different frequencies and intensities are successful applications in terms of user experience.

d) The fact that aquarium kiosks offer an interactive content with social values demonstrates the power of the user experience provided.

e) In the aquarium scenario, the kiosks designed to serve users of all age groups attracts attention due to illuminated digital screen as they are not physically perceived in dark places.

f) The laboratory product is more unique and experience-oriented than urban kiosks in terms of interaction and user experience. This is because of the fact that urban kiosks are designed with goals on service, not user experience related to edutainment. Therefore, public service kiosk could be reconsidered based on similar approaches regarding user experience.

g) Products designed specifically for the aquarium project work with the energy reflected from the building. The product, which has achieved high success in terms of ergonomics and ease of use, is positioned multiple times in the entire structure, allowing everyone to obtain information on the content and achieving satisfactory service success.

h) As the content is heavily detailed, advanced game software was preferred on the fish database kiosk due to the large amount of information that could not be provided by a tour guide.

i) Major differences among urban kiosks can be observed from the evaluation criteria, but it is possible to claim that all kiosks are adequately functional and Cinebonus kiosks are aesthetically more advanced compared other products presented.

j) Physical aspects of urban kiosks are highly evident and appropriate with the texture of the city, meanwhile aquarium kiosks are vaguely hidden from sight attracting attention in case of need. Aquarium kiosks are presented as a part of the spatial design 
scenario and do not need to be perceived individually. Urban kiosks are aesthetically stronger compared to the aquarium kiosk, this comment is based on the finding that urban kiosks prompt target users receiving service upon invitation.

k) On aquarium products interaction time experienced varies according to the level of interest and curiosity of the user on the content. As a result of the unique content that invites visitors, a memorable process is experienced. In urban products, there is an invitation to service rather than an invitation to experience that constitutes the foundation of the study.

As a fact, ergonomics covers two different areas, physical ergonomics referring to the form and dimensions of the object and interface ergonomics covering the use of ease of the digital content. For an interface to be sufficiently ergonomic, color, typography, screen resolution and illumination have a role on determining the level of quality. The features of ergonomic virtual systems are examined in line with the objectives of the study and the basic findings are explained. In this context, a system that is familiar to the user, provides efficient and contextual continuity, is compatible with demographic features and user identities as well as conforming to usability criteria. In the study, two different factions of kiosks are presented and evaluated in order to provide an insight on the differences of scale concerning the design and service qualities of the products. The reason for this preference is also to be able to make discoveries on products designed for a project by determining the characteristics of high usage frequency urban products. Since the goal in urban products is to receive service rather than the value of experience, the interaction takes place and ends as soon as the product is recognized spatially. Just as in major scientific approaches, in ergonomics science while examining human and product systems, it is logical to make some acceptances proven by experimental and applied studies. These acceptances provide an infrastructure for scientific studies as reference as well as constituting an anchor point necessary for the progress of research.

\section{Discussion}

The efficiency of human-product systems is correlated with the efficiency of human performance within the system. If the user cannot perform the functions within the system effectively, the performance of the system will also be negatively affected. Another acceptance is the assumption that a person will be more successful when properly motivated. Designers should be able to create more appropriate spaces by working on the work environment characteristics that affect the individual. The design of equipment, station, machinery and environmental conditions in order to increase the efficiency of people in work environments, is the most important step in achieving the targeted results. Technological advances in line with scientific approaches such as ergonomics are proof that interactive products keep on developing further.

The study draws attention to an interactive urban furniture that is not always perceived except for in times of need, despite the intensive use in daily life. For the future studies, it is possible to examine the interaction types created by kiosks specific to selected projects based on cognitive skills and functions. Public service kiosks are a result of the modern urbanism understanding and an important interactive product group used by the city dwellers for certain services. These products need to be designed in accordance with the urban texture, service goals and user profiles as much as possible. Although design and ergonomics are two separate disciplines, they function as two parts of a whole, complementary to each other. It is possible to see ergonomics as an approach within sociology and call it 'design for the public', due to its orientation on the design of products, workplaces and systems. In a crowded city life, it is essential to use interactive products in terms of needs that need to be met quickly in the dynamics of life.

The study follows a methodological approach in which the public service kiosks are presented and elaborated on evaluative charts setting an infrastructure for the case study product. Therefore, the main scope of the article is the evaluation of the case study project and presenting results regarding the process. Dimensions of kiosks, screens and slots differ providing a wide range of diverse products with various design languages (Stone \& Wood, 2000) and readability (Narter, 2019). Service quality aspects of kiosk varying on multiple elements such as content, location and focus of service. Technological aspects of kiosk encompass mostly touch technologies and seldom analog systems such as ticket and token slots. Kiosk ergonomic evaluation has been made centered on the physical and virtual qualities of products based on observative usage frequencies, on-site analysis of virtual interfaces and compatibility between these aspects. Detection regarding interface qualities of kiosk depend on overall user experience values as expressed by (Blair-Early and Zender, 2008). Design orientation of products refers to the multidisciplinary nature of kiosks as mentioned by (Ekșioğlu, 2016). It is possible to assume that kiosks with tangible structures and virtual interfaces are products centered on a multidisciplinary approach. Spatial 
orientation of kiosk imply to the location in which the product has been placed which can be an indoor or an outdoor implementation. This quality has an effect on infrastructural features that determines the essential source of energy. As it can be observed from evaluative charts, outdoor kiosk use municipal infrastructure and indoor kiosks use structural infrastructure as sources of energy. Solar powered kiosks are not used in the city where the research has been conducted. Interaction types refer to the style of interaction taking place. Shedroff (1994), classifies interaction as direct, indirect and accidental. Direct interaction takes place where a physical and voluntary manipulation is required. Indirect interaction is mostly relevant on scenarios related to gesture recognition systems. Accidental interaction occurs in cases when the subject is not aware of the possibility of interactivity such as motion sensors at the shop entrances, implying to the fact that this type of interaction has a coincidental value. Screen interaction styles refers to the touch technology used on the touch screen as mentioned by Hagen and Sandnes (2010). Touch technologies can be implemented as single, double or multi-touch interaction styles. All implementations of kiosks function on single-touch interactions.

The study provides basic concepts on the subject and the relationship between the examples and the case study kiosk evaluated. Presenting kiosks with different locations, functions and services simultaneously is essential for the purpose on determining the scope of the study. Following the examples presented, the inclusion of a product designed by the author constitutes a point of reference in terms of the evaluation process. For future studies it is possible to conduct a research based on tangible data and user experience-oriented edutainment design approach that can be applied to a product through the in-depth examination of public service kiosks.

\section{Appreciation}

Thank you to my colleagues and partners for the support and direction provided during the research, development and finalization stages of the study

\section{Conflict of Interest}

No conflict of interest was declared by the authors.

\section{References}

Bayrakçı, O. (2004). Çağdaş İletişim Kuramları Açısından Tasarımda İletişimsel Modeller, Mimar
Sinan Güzel Sanatlar Üniversitesi. İstanbul, Barkod No: 9789759736306.

Berkley, B.J. and Gupta, A. (1994). Improving Service Quality with Information Technology, International Journal of Information Management, Volume 14, Issue 2,109-121, ISSN 0268-4012.

Blair-Early, A. and Zender, M. (2008). User Interface Design Principles for Interaction Design. Design Issues. 24. 85-107. 10.1162/desi.2008.24.3.85.

Brandejsky, M. and Kilzer, F. (2006). Virtual Reality in Edutainment: A State of The Art Report, MSc project, Technischen Universität Wien. Available http://www.brandejsky.com/pdfs/VirtualReality-in-Edutainment.pdf

Chaudhary, A., Raheja, J. L., Das, K., and Raheja, S. (2010). A Survey on Hand Gesture Recognition in Context of Soft Computing, The British Computer Society, 46-55.

Csikszentmihalyi, M. (1998). Finding Flow: The Psychology of Engagement with Everyday Life. Basic Books, New York.

Ekşioğlu, M. (2016). User Experience Design of a Prototype Kiosk: A Case for the İstanbul Public Transportation System, International Journal of Human-Computer Interaction, 32:10, 802-813, DOI: $10.1080 / 10447318.2016 .1199179$.

Fogg, B. J. (2002). Computers as Persuasive Social Actors. Persuasive Technology, https://dl.acm.org/doi/pdf/10.1145/764008.76 3957.

Hagen, S. and Sandnes, F. E. (2010). Toward Accessible Self-Service Kiosks Through Intelligent User Interfaces. Pers Ubiquit Comput 14, 715-721. doi.org/10.1007/s00779-0100286-8

Jengchung V. Chen, David Yen, Kimberly Dunk and Andree E. Widjaja (2015) The Impact of Using Kiosk on Enterprise Systems in Service Industry, Enterprise Information Systems, 9:8, 835-860, doi: $10.1080 / 17517575.2013 .867542$

Kavut, İ. E. (2019). Günümüz Mutfağı; Bir Sistemin Doğurduğu Mobilyalar. Doğu Fen Bilimleri Dergisi, 3 (1), Retrieved from 
https://dergipark.org.tr/en/pub/dfbd/issue/53 475/654723, 2019, s. 61.

La Ville, A. (1976). 'I'Ergonomie', PUF Paris, France.

Lao, S., Heng, X. Guohua, Z., Yunxiang, L. and Wang, P. (2009). A Gestural Interaction Design Model for Multi-Touch Displays, HCI, People and Computers XXIII. Celebrating People and Technology.

Liu, Y. (1997). Software-User Interface, Handbook of Human Factors and Ergonomics. Ed: Gavriel Salvendy. New York: John Wiley \& Sons, Inc.

Nam, T. J. and Kim, C. (2011). Design by Tangible Stories, International Journal of Design, Vol 5 No 1.

Narter, Ç. (2019). Elektronik İletişim Araçları Etkileşim Tasarımı Alanında Haptik Arayüz ve Kullanıcı Gruplarında Ürün Okunabilirliği Olgusu. Online Journal of Art and Design, Volume 7, issue 2, April.

Reed, P., Holdaway, K., Isensee, S., Buie, E., Fox, J., Williams, J. and Lund, A. (1999). User Interface Guidelines and Standards: Progress, Issues, and Prospects', Interacting with Computers, 12.

Shedroff, N. (1994). Information Interaction Design, A Unified Theory Field of Design. Vivid Publishing, Australia.

Stone, R. and Wood, K. (2000). Development of a Functional Basis for Design. Journal of Mechanical Design - J Mech Design. 122. 10.1115/1.1289637.

Swamy, J. C. N., Seshachalam, D. and Shariff, S. U. (2016). Smart RFID Based Interactive Kiosk Cart Using Wireless Sensor Node, International Conference on Computation System and Information Technology for Sustainable Solutions (CSITSS), Bengaluru, India, 2016, pp. 459-464, doi: 10.1109/CSITSS.2016.7779426.

Yum, M.S. (2015). The Exploration of Interactive Interfaces and Products in Edutainment: The Istanbul Aquarium'. ITU Department of Industrial Product Design, Master Thesis, 2015. 104-105. 